\title{
Rethinking therapeutic decisions for hepatitis B infection in Syria: insights into molecular monitoring
}

\author{
Wafa Habbal and Fawza Monem \\ Clinical Laboratories Department, Al-Assad Hospital, Damascus University, Damascus, Syria
}

\begin{abstract}
Introduction: Hepatitis B virus patients are usually treated in Syria with alpha interferon and nucleos(t)ide analogues. Genotypic viral factors causing inadequate response or relapse following initial response are not routinely investigated. This study aimed to explore and discuss local therapeutic decisions from a molecular perspective.

Methodology: Fifty patients with hepatitis B from Syria were tested for HBV genotyping and drug-resistance mutations by DNA sequencing. Results: All patients had genotype D, which is characterized by relatively low response to interferon-based therapy. Drug-resistant viral mutant variants were detected in one fifth of the enrolled patients, and distributed similarly in both nucleos(t)ide analogues-naïve and -treated patients. However, nucleos(t)ide analogues-based therapy was associated with the existence of more mutations and hence increased resistance.

Conclusions: Investigating HBV genotypes and drug-resistance mutations to support treatment decisions is critically needed for efficient therapy and patients' survival.
\end{abstract}

Key words: hepatitis B virus; Syria; therapeutic decisions; viral genotype; mutant variants; drug resistance

J Infect Dev Ctries 2012; 6(10):744-747.

(Received 13 February 2012 - Accepted 02 April 2012)

Copyright (C) 2012 Habbal and Monem. This is an open-access article distributed under the Creative Commons Attribution License, which permits unrestricted use, distribution, and reproduction in any medium, provided the original work is properly cited.

\section{Introduction}

Hepatitis B virus (HBV) infection is a highly prevalent disease worldwide and considered a major public health problem [1]. Chronically infected patients are at high risk of cirrhosis and hepatocellular carcinoma (HCC) [2], while recommended management is limited to the treatment of its complications and antiviral therapy [3]. HBV demonstrates a high mutation rate due to its errorprone reverse transcriptase that lacks exonuclease proofreading activity [4]. Hence drug-resistant variants may emerge throughout nucleos(t)ide analogues-based therapy leading to relapse and hepatic decompensation $[5,6]$. Moreover, the HBV genotype plays an essential role in driving viral evolution [5] as well as response to interferon-based therapy $[7,8]$.

In Syria, hepatitis B patients are treated with either interferon alpha (INF- $\alpha$ ) or nucleos(t)ide analogues, such as Lamivudine (LMV) and Adefovir (ADV). Because they are the only drugs approved by the national drug committee, they are solely recommended by the national guidelines for hepatitis B management considering INF- $\alpha$ as the first-line therapy [9]. Currently, therapeutic decisions are based on viral
DNA load in patients' sera which is inadequately informative as to the reason behind frequently encountered cases of relapse or inadequate response to treatment. These cases remain unexplained and problematic to manage appropriately. This study aimed to explore the appropriateness of local therapeutic decisions in view of the genotypic viral factors influencing response to therapy in a group of hepatitis B patients with high viral loads.

\section{Methodology}

Serum samples from fifty Syrian hepatitis B patients with high viral loads were drawn between August 2008 and April 2010 after obtaining informed consent. Sera viral loads were more than $6 \log$ with an average of $1.45 \mathrm{E}+9$ copies $/ \mathrm{ml} \quad(1.83 \mathrm{E}+6-1.98 \mathrm{E}+10$ copies $/ \mathrm{ml}$ ) in both treatment-naïve (26 of 50,52\%) and treated $(24$ of $50,48 \%)$ patients when enrolled in the study. Information on applied therapeutic plans was obtained from the patients' medical records. Twenty-four patients were treated with either interferon monotherapy ( 9 of 50,18\%) for 8 months (3-18 months), or interferon and nucleos(t)ide 
Table. Nucleos(t)ide analogues resistance mutations detected in Syrian hepatitis B patients $(\mathrm{n}=50)^{a}$

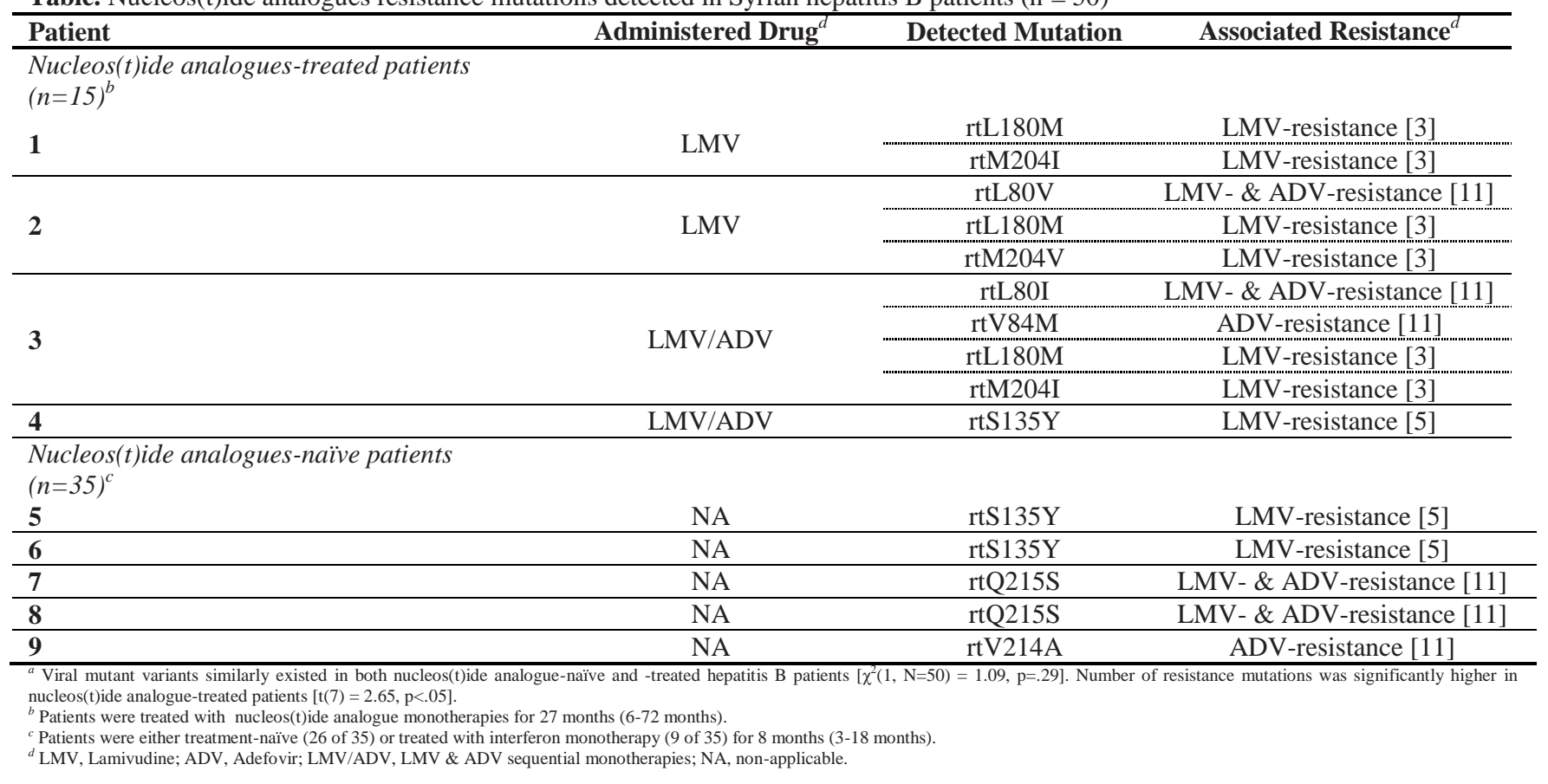

analogues sequential monotherapies (15 of 50, 30\%) for 27 months (6-72 months).

Viral DNA was extracted using a High Pure Viral Nucleic Acid Kit (Roche Diagnostics, Germany). The entire viral pre-S1/pre-S2/S gene region was amplified in a $50 \mu \mathrm{l}$-volume reaction containing $1 \mu \mathrm{M}$ of each primer (forward, 5'-GGG TCA CCW TAT WCY TGG GAA-3'; reverse, 5'-CGT TGC CKR GCA ACS GGG TAA AGG-3'; TIB MOLBIOL, Berlin, Germany), $1.5 \mathrm{mM}$ of $\mathrm{MgCl} 2$ and $5 \mu \mathrm{l}$ of extracted DNA using a GeneAmp High Fidelity PCR System (Applied Biosystems, Foster City, CA, USA). Thermal cycling profile was initiated at $94^{\circ} \mathrm{C}$ for 2 minutes followed by 40 cycles of denaturation at $94^{\circ} \mathrm{C}$ for 15 seconds, annealing at $55^{\circ} \mathrm{C}$ for 30 seconds with an extension at $72^{\circ} \mathrm{C}$ for 3 minutes. An additional extension time of 5 seconds per cycle after cycle 10 and a final extension step at $72^{\circ} \mathrm{C}$ for 7 minutes were added. Direct sequencing was performed on an ABI PRISM 3100-Avant Genetic Analyzer (Applied Biosystems, Foster City, CA, USA) using previously described primers $[10,11]$. Viral nucleotide sequences were subtyped using the NCBI Genotyping tool and Bayesian phylogenetic analysis. Predicted protein translations were searched for thirty mutations previously reported as associated with viral resistance against various nucleos(t)ide analogues including rtL80V/I, rtV84M, rtS85A, rtS135Y, rtI169T, rtV173L, rtL180M/C, rtA181T/V/S, rtT184G/A/S,
rtA194T, rtS202I/G, rtM204V/I/S, rtV214A, rtQ215S, $\mathrm{rtL} 229 \mathrm{~V}, \quad \mathrm{rtN} 236 \mathrm{~T}, \quad \mathrm{rtP} 237 \mathrm{H}, \quad \mathrm{rtN} 238 \mathrm{~T} / \mathrm{D}$ and rtM250V/L [3,5,12]. Chi square and Student's t tests were used to analyze mutation distribution among nucleos $(\mathrm{t})$ ide analogues-naïve and -treated patients. Viral nucleotide sequences related to our study were assigned GenBank accession numbers from JN257148 to JN257217.

\section{Results}

Genotype D was assigned to all obtained viral nucleotide sequences. LMV- and/or ADV-resistant viral mutant variants were detected in nine patients $(9$ of $50,18 \%$ ). Up to 4 mutations of $\mathrm{rtL} 80 \mathrm{~V} / \mathrm{I}, \mathrm{rtV} 84 \mathrm{M}$, $\mathrm{rtS135Y,} \mathrm{rtL180M} \mathrm{and/or} \mathrm{rtM204V/I} \mathrm{were} \mathrm{detected} \mathrm{in}$ 4 patients (4 of 15, 27\%) treated with nucleos(t)ide analogues, while one mutation of rtS135Y, rtV214A or rtQ215S was detected in 5 recently diagnosed treatment-naïve patients ( 5 of $35,14 \%$ ) [Table].

Viral mutant variants similarly existed in both nucleos(t)ide analogue-naïve and -treated hepatitis $\mathrm{B}$ patients $[\chi 2(1, \mathrm{~N}=50)=1.09, \mathrm{p}=.29]$. However, the number of resistance mutations was significantly higher in nucleos $(\mathrm{t})$ ide analogue-treated patients $[\mathrm{t}(7)$ $=2.65, \mathrm{p}<.05]$.

\section{Discussion}

Our findings indicate the dominance of genotype $\mathrm{D}$ in Syria, which is consistent with its high prevalence 
in the Mediterranean region [2,13]. Despite the reported association of genotype $\mathrm{D}$ with poor response to interferon-based therapeutic regimens [7,8,14], interferon alpha is routinely prescribed as the first-line therapy to hepatitis B patients in Syria [9]. Interestingly, altering the therapeutic plan from interferon alpha to nucleos(t)ide analogues monotherapies had already been indicated by physicians for two thirds (15 of $24,63 \%)$ of the treated patients, inferring the ineffectiveness of interferonbased therapy, as shown in the present study. Selecting effective therapeutic plans is critically needed due to the reported association of genotype D with high risk of severe liver disease, recurrence, and fulminant hepatitis [2,7]. Fortunately, genotype D influence on driving viral evolution leading to the emergence of resistance mutations under nucleos(t)ide analogues pressure is relatively low $[5,14]$. Thus considering HBV genotype is crucial for therapeutic decision making whether by interferon or nucleos(t)ide analogues [8].

Viral mutant variants similarly existed in both nucleos(t)ide analogue-naïve and -treated hepatitis B patients. Hence investigating resistance mutations beforehand is recommended for efficient drug prescription. Moreover, monitoring drug-resistant mutants during nucleos $(\mathrm{t})$ ide analogues treatment is necessary to ensure early detection of potentially emerging mutations before considerable serum viral load increase in the patient occurs $[3,5,15]$. This necessity is underscored by our findings of detecting multiple resistance mutations in LMV/ADV-treated patients whose therapeutic plans were continued due to lack of awareness of the critical necessity of timely rescue therapy, and hence were at high risk of mutant selection that led to viral breakthrough, and might lead to hepatitis flare, hepatic decompensation and death $[3,15]$.

In conclusion, the critical need for evidence-based therapeutic decisions urges review of local established therapeutic regimens. National guidelines should be updated taking into account the dominance of genotype D in Syria and considering more efficacious nucleos $(\mathrm{t})$ ide analogues with high barriers to resistance, such as Entecavir and Tenofovir [16] Additional molecular investigations, such as HBV genotypes and drug-resistant mutations, should also be considered for efficient therapies and patients' survival.

\section{References}

1. Aung MN, Leowattana W, Tangpukdee N, Kittitrakul C (2011) Observation of genotype C infected chronic hepatitis B patients in clinical practice. J Infect Dev Ctries 5: 882-889.

2. Hannachi N, Fredj NB, Bahri O, Thibault V, Ferjani A, Gharbi J, Triki H, Boukadida J (2010) Molecular analysis of HBV genotypes and subgenotypes in the Central-East region of Tunisia. Virol J 7: 302.

3. Kim JK, Lee HJ, Lee YJ, Chun JY, Lee IK, Lim YS, Suh DJ, Ko SY, Kim MH, Oh HB (2008) Direct detection of lamivudine-resistant hepatitis B virus mutants by a multiplex PCR using dual-priming oligonucleotide primers. J Virol Methods 149: 76-84.

4. Zhang Q, Cao G (2011) Genotypes, mutations, and viral load of hepatitis B virus and the risk of hepatocellular carcinoma: HBV properties and hepatocarcinogenesis. Hepat Mon 11: 8691.

5. Svicher V, Gori C, Trignetti M, Visca M, Micheli V, Bernassola M, Salpini R, Gubertini G, Longo R, Niero F, Ceccherini-Silberstein F, De Sanctis GM, Spanò A, Cappiello G, Perno CF (2009) The profile of mutational clusters associated with lamivudine resistance can be constrained by HBV genotypes. J Hepatol 50: 461-470.

6. Luan J, Yuan J, Li X, Jin S, Yu L, Liao M, Zhang H, Xu C, He Q, Wen B, Zhong X, Chen X, Chan HL, Sung JJ, Zhou B, Ding C (2009) Multiplex detection of 60 hepatitis B virus variants by maldi-tof mass spectrometry. Clin Chem 55: 1503-1509.

7. Ding L, Rui C, Zhansheng J, Xiangling W, Ping L, Zhen Y, Yanhai G, Ju Z (2010) Detection of hepatitis B virus genotypes $\mathrm{A}$ to $\mathrm{D}$ by the fluorescence polarization assay based on asymmetric PCR. J Virol Methods 168: 31-37.

8. Amini-Bavil-Olyaee S, Pourkarim MR, Schaefer S, Mahboudi F, Van Ranst M, Adeli A, Trautwein C, Tacke F (2011) Single-step real-time PCR to quantify hepatitis B virus and distinguish genotype D from non-D genotypes. J Viral Hepat 18: 300-304.

9. Syrian Working Group for the Study of Viral Hepatitis (2006) Management of hepatitis B national guidelines, 3rd edition. Syria: Syrian Society of Gastroenterology $36 \mathrm{p}$.

10. Chan HL, Tsui SK, Tse CH, Ng EY, Au TC, Yuen L, Bartholomeusz A, Leung KS, Lee KH, Locarnini S, Sung JJ (2005) Epidemiological and virological characteristics of 2 subgroups of hepatitis B virus genotype C. J Infect Dis 191: 2022-2032.

11. Kato H, Fujiwara K, Gish RG, Sakugawa H, Yoshizawa H, Sugauchi F, Orito E, Ueda R, Tanaka Y, Kato T, Miyakawa Y, Mizokami M (2005) Classifying genotype F of hepatitis B virus into F1 and F2 subtypes. World J Gastroenterol 11: 6295-6304.

12. Shaw T, Bartholomeusz A, Locarnini S (2006) HBV drug resistance: mechanisms, detection and interpretation. J Hepatol 44: 593-606.

13. Antaki N, Haffar S, Ali Deeb S, Assaad F, Abou Harb R, Zeibane N, Nasserelddine M, Ibrahim N, Alhaj N, Jabbour E, Aaraj R, Antaki F, Kebbewar K (2010) High prevalence of HBV genotype D in Syria and the clinical characteristics of hepatitis B e antigen-negative chronic hepatitis B. Epidemiol Infect 138: 40-44.

14. Liu WC, Lindh M, Buti M, Phiet PH, Mizokami M, Li HH, Sun KT, Young KC, Cheng PN, Wu IC, Chang TT (2008) Genotyping of hepatitis B virus--genotypes a to $\mathrm{g}$ by 
multiplex polymerase chain reaction. Intervirology 51: 247252.

15. Peng XM, Gu L, Huang YS, Ma HH, Xie QF, Li G, Gao ZL (2005) Simultaneous detection of two major lamivudineresistant mutants using competitively differentiated-PCR. J Virol Methods 128: 168-175.

16. European Association for the Study of the Liver (2009) EASL Clinical Practice Guidelines: management of chronic hepatitis B. J Hepatol 50: 227-242.

\section{Corresponding author}

Wafa Habbal

Clinical Laboratories Department

Al-Assad Hospital, Damascus University

PO Box 10769, Damascus, Syria

Phone: +963-11-21942320

Fax: +963-11-2139441

Email:wafahabbal@hotmail.com

Conflict of interests: No conflict of interests is declared. 